\title{
An investigation on relationship between residual income and internal and external performance measures
}

\author{
Hesam Daryani $^{\mathrm{a}^{*}}$ and Seyed Yousef Ahadi Serkani ${ }^{\mathrm{b}}$
}

${ }^{a}$ M.A. Student, Department of Accounting, School of Management, Tehran North Branch, Islamic Azad University (IAU), Tehran, Iran ${ }^{b}$ Assist.Prof. \& Faculty Member, Department of Accounting, Firoozkooh Branch, Islamic Azad University (IAU), Iran

\begin{tabular}{|c|c|}
\hline A R T I C L E I N F O & A B S T R A C T \\
\hline $\begin{array}{l}\text { Article history: } \\
\text { Received August 10, } 2012 \\
\text { Accepted } 28 \text { September } 2012 \\
\text { Available online } \\
\text { September } 282012 \\
\text { Keywords: } \\
\text { Residual income } \\
\text { Operating cash flow } \\
\text { Tehran stock exchange }\end{array}$ & $\begin{array}{l}\text { During the past few years, there have been growing interest in learning the relationship between } \\
\text { residual income and other financial figures such as dividend per share, market value and } \\
\text { operating cash flow. The proposed study of this paper gathers the financial information of all } \\
\text { listed firms traded in Tehran Stock Exchange over the period of 2007-2011. We only } \\
\text { concentrate on listed companies whose fiscal years started from March to May of each year. } \\
\text { The other criterion associated with the proposed study of this paper is that shares of the selected } \\
\text { firms must have been active during period of study and there must be no change in their fiscal } \\
\text { calendar. The study does not include the shares of holdings, banks, insurance firms. Finally, the } \\
\text { information of the firms must be available for course of study. The study uses two regressions } \\
\text { analysis and examines five hypotheses including the relationship between residual income and } \\
\text { other factors including dividend per share, value added operating cash flow, value added cash } \\
\text { flow, market cap and market value added. Using two regression models, all these hypotheses } \\
\text { are investigated and the results of the survey confirm a meaningful relationship between } \\
\text { residual income and dividend per share, value added operating cash flow, value added cash } \\
\text { flow. However, the results of the second model do not confirm the last two hypotheses. }\end{array}$ \\
\hline
\end{tabular}

\section{Introduction}

During the past few years, there have been growing interests on learning more about the impact of residual income on other financial figures such as operating cash flow, dividend per share, etc. (Worthington \& West, 2004; Reddy Irala, 2005). In fact, there are some evidences to believe that an increase on residual income positively impact on overall market (Hall \& Brummer, 1999). There are also other related works associated with market behavior. Magni (2009), for instance, performed a comprehensive investigation on capital budgeting decisions, sales and production and decisions, use of optimal portfolios, prediction of asset prices and estimation of intrinsic values. Magni (2010), in another assignment, performed an in depth investigation on residual income and value creation and * Corresponding author. Tel: +989351511849

E-mail addresses: hesam.daryani@gmail.com (H. Daryani) 
proposed a new method for measuring residual income. Lin et al. (2011) tried to understand whether stock prices of stock-financed acquirers could move in direction of their fundamental value in long term and whether they could correct their initial overvaluation. Their results indicated that more overvalued acquirers were related to weaker post-acquisition returns.

Athanasoulis and Shiller (2002) studied a new technique of decomposing the variance of national incomes into components to determine the most influencing 'residual' risk-sharing opportunities among peoples of the world. Keller and Siegrist (2006) studied the impact of financial risk behavior, money achievement and negative ethical stance towards the stock market, income, and gender on willingness to purchase stocks. They reported that income was a substantial positive predictor for men with an investment account. In addition, money attitude budget was an important negative predictor for men and women who do not maintain an investment account. On the contrary, achievement had no substantial impact on willingness to invest in stocks.

Machuga et al. (2002) studied economic value added, future accounting earnings, and financial analysts' earnings per share predictions. Pan et al. (2007) performed a comprehensive study on the dynamic responses of stock prices to shocks measured by earnings and dividends. They decomposed historical information of aggregate earnings, stock prices and dividend into permanent and transitory components among three data series. They reported that approximately $95 \%$ of the variation in stock returns could be described by permanent earnings and permanent dividends.

The proposed study of this paper gathers the financial information of all listed firms traded in Tehran Stock Exchange over the period of 2007-2011. The organization of this paper first presents details of our statement in section 2. Section 3 presents details of our findings and finally, concluding remarks are given in the last to summarize results of the paper.

\section{The proposed method}

The proposed model of this paper considers the following five hypotheses,

1. There is a meaningful relationship between residual income and dividend per share.

2. There is a meaningful relationship between residual income and value added operating cash flow.

3. There is a meaningful relationship between residual income and cash value added.

4. There is a meaningful relationship between residual income and market cap.

5. There is a meaningful relationship between residual income and market value added.

The proposed study of this paper gathers the financial information of all listed firms traded in Tehran Stock Exchange over the period of 2007-2011. The proposed study only focused on listed companies whose fiscal years started from March to May of each year. The other criterion associated with the proposed study of this paper is that shares of the selected firms must have been active during period of study and there must be no change in their fiscal calendar. The study did not include the shares of holdings, banks, insurance firms. Finally, the information of the firms must be available for course of study.

\subsection{Variables}

\subsubsection{Residual income}

Residual income is calculated as a difference between revenue, capital cost of equities, and it is calculated as follows, 


$$
R I_{i, t}=N I_{i, t}-\left(r_{i, t} \times B V_{i, t-1}\right) \text {, }
$$

where $R I_{i, t}$ is the residual income of firm $i$ in year $t, N I_{i, t}$ is the net income of firm $i$ in year $t$ and it is extracted from the firm's statement, $B V_{i, t-1}$ is the book value of firm $i$ in year $t$ and finally

\subsubsection{Cost of capital}

Cost of capital, $r_{i, t}$ is cost of capital of firm $i$ in year $t$ and it is calculated as follows,

$$
r_{i, t}=k e\left(\frac{S_{i, t}}{D_{i, t}+S_{i, t}}\right)+k d\left(\frac{D_{i, t}}{D_{i, t}+S_{i, t}}\right)
$$

where $S_{i, t}$ is the average value of equities of firm $i$ in year $t, D_{i, t}$ is average of all liabilities of firm $i$ in year $t$.

\subsubsection{Cost of borrowing}

Cost of borrowing $(k d)$ of firm $i$ in year $t$ is calculated as follows

$$
k d=\frac{I C}{S T F+L T F}(1-T R)
$$

where IC is the interest cost, STF is the short term financing, $L T F$ is the long term financing and $T R$ is tax rate.

\subsubsection{Cost of equity}

Cost of equity (ke) of firm $i$ in year $t$ is calculated as follows,

$$
k e=\frac{D}{P_{0}}+g
$$

where $D$ is the dividend per share, $P_{0}$ is share price before annual meeting and $g$ is growth rate calculated using geometric mean in a three-year period. Dividend per share (DPS) is determined normally when the regular annual meeting is held and it is a portion of earning per share (EPS). Operating cash flow is another important measure, which must be accomplished in long term for the survival of the firm. Cash value added (CVA) represents the created wealth in a fiscal year and in this paper we calculated as follows,

$$
C V A_{, t}=D P_{i, t}+I P_{i, t}+S P_{i, t}+T P_{i, t}+C F O_{i, t},
$$

where $C V A_{i, t}$ is cash value added of firm $i$ in year $t, D P_{i, t}$ is dividend per share of firm $i$ in year $t$, $I P_{i, t}$ is the cost of interest of firm $i$ in year $t, S P_{i, t}$ is sum of equities of firm $i$ in year $t, T P_{i, t}$ is paid Tax of firm $i$ in year $t$ and finally, $C F O_{i, t}$ is operating cash flow of firm $i$ in year $t$, respectively.

\subsubsection{Market Value (MV)}

Market value is calculated by multiplying the number of shares by market price at the end of each fiscal year. 


\subsubsection{Market Value Added (MVA)}

Market value added is calculated as the difference between market value $\left(M V_{i, t}\right)$ and investment capital $\left(I C_{i, t}\right)$ for firm $i$ in year $t$ as follows,

$$
M V A_{, t}=M V_{i, t}-I C_{i, t}
$$

and $I C_{i, t}$ is calculated as the sum of net book value of fixed assets $\left(F A_{i, t}\right)$ and working capital ( $W C_{i, t}$ ) for firm $i$ in year $t$.

The proposed model of this paper considers the following two models for studying the behavior of residual income as follows,

$$
\begin{aligned}
& R I_{i, t}=\beta_{0}+\beta_{1} D P S_{i, t}+\beta_{2} O C F_{i, t}+\beta_{3} C V A_{i, t}+\varepsilon_{i t} \\
& R I_{i, t}=\beta_{0}+\beta_{1} M V_{i, t}+\beta_{2} M V A_{i, t}+\varepsilon_{i t}
\end{aligned}
$$

Table 1 shows details of some statistical observations including the number of observations $(\mathrm{N})$, mean, standard deviation, min and max, skewness and string.

\section{Table 1}

Statistical observations of the input data

\begin{tabular}{llllllll}
\hline & $\mathrm{N}$ & Mean & Std. dev. & $\min$ & $\max$ & Skewness & String \\
\hline$R I$ & 864 & 864.64 & 1132.4 & -6457.76 & 6953.06 & 1.237 & 7.810 \\
DPS & 864 & 797.26 & 941.29 & 0 & 7300 & 2.877 & 11.276 \\
OCF & 862 & 1030.63 & 1584.28 & -4928.76 & 23315.56 & 4.969 & 52.111 \\
CVA & 862 & 3925.47 & 3764.99 & 207.17 & 53249.85 & 5.110 & 47.187 \\
MV & 864 & 7028.95 & 10110.94 & 535.00 & 92502.00 & 4.352 & 24.054 \\
MVA & 861 & 5426.34 & 10711.21 & -2736.62 & 89871.92 & 4.199 & 21.594 \\
\hline
\end{tabular}

Based on the results of Table 1, we realize that we can perform the regression analysis on both models using panel data.

\section{The results}

The first three hypotheses of this survey are validated based on Eq. (1) using panel data and when all three coefficients of $\beta_{1}, \beta_{2}$ and $\beta_{3}$ are statistically meaningful we can confirm all of them. The results of Chaw test yield F-value of 1.487 with P-value of 0.0019 while Chi-Square value for Haman test is 19.706 with P-value of 0.0002 . These are preliminary results for validating the model when the level of significance is 5\%. In addition, we have performed Breusch-Pagan test where F-value is calculated as 3.003 with P-value of 0.0292 and Durbin-Watson has been calculated as 2.04. These statistical observations confirm the results.

$$
\begin{aligned}
& R I_{i, t}=-311.47+0.8070 D P S_{i, t}-0.1174 O C F_{i, t}+0.1115 C V A_{i, t}+\varepsilon_{i t} \\
& \text { t-student (-7.093) (20.542) (-4.286) (8.515) } R^{2}=0.7421 F=19.650 P \text {-value }=0.000
\end{aligned}
$$

As we can observe from the results of t-student value given in Eq. (9), all coefficients are statistically meaningful when the level of significance is five percent. R-Square yields 0.7421 , which means the independent variables can describe approximately $74 \%$ of the changes in dependent variable. In 
summary, we can conclude that an increase of one unit in dividend per share can increase residual income by 0.8070 while an increase of one unit in operating cash flow will reduce residual income by 0.1174 and finally an increase of one unit in value added cash flow will increase residual income by 0.1115 . F-value is statistically meaningful when the level of significance is $5 \%$ and this means there is a linear relationship between independent and dependent variables.

Hypotheses five and six of this survey are validated based on Eq. (2) using panel data and when all three coefficients $\beta_{0}, \beta_{1}$ and $\beta_{2}$ are statistically meaningful we can confirm both hypotheses. The results of Chaw test yield F-value of 3.538 with P-value of 0.000 while Chi-Square value for Haman test is 43.480 with P-value of 0.000 . These are preliminary results for validating the model when the level of significance is $5 \%$. In addition, we have performed Breusch-Pagan test where F-value is calculated as 23.959 with P-value of 0.000 and Durbin-Watson has been calculated as 1.79. These statistical observations confirm the results.

$$
\begin{aligned}
& R I_{i, t}=253.40+0.0493 M V_{i, t}+0.0074 M V A_{i, t}+\varepsilon_{i t} \\
& \text { t-student (7.315) (6.546) } \quad \text { (1.103) } \quad R^{2}=0.6608 F=13.427 P-\text { value }=0.000
\end{aligned}
$$

As we can observe from the results of t-student value given in Eq. (9), t-student associated with $M V$ is statistically meaningful, which confirms the fourth hypothesis while t-student associated with MVA is not statistically meaningful and we cannot confirm the fifth hypothesis. R-square yields 0.6608 , which means the independent variables can describe approximately $66 \%$ of the changes in dependent variable. In summary, we can conclude that an increase of one percent in $M V$ will increase 0.0493 unit in residual income.

\section{Conclusion}

In this paper, we have presented an empirical study to investigate the relationship between residual income and other revenue based items such as dividend, operating cash flow, etc. The proposed study of this paper gathered the financial information of all listed firms traded in Tehran Stock Exchange over the period of 2007-2011. We only focused on listed companies whose fiscal years started from March to May of each year. The other criterion associated with the proposed study of this paper is that shares of the selected firms must have been active during period of study and there must be no change in their fiscal calendar. The study did not include the shares of holdings, banks, insurance firms. Finally, the information of the firms must be available for course of study.

The study used two linear regressions analysis and examined five hypotheses including the relationship between residual income and other factors including dividend per share, value added operating cash flow, value added cash flow, market cap and market value added. Using two regression models, all these hypotheses have been investigated and the results of the survey confirmed a meaningful relationship between residual income and dividend per share, value added operating cash flow, value added cash flow. However, the results of the second model do not confirm the last two hypotheses.

\section{Acknowledgment}

The authors are grateful for comments on earlier version of this paper specially the one, which was as long as the first draft of the paper. 


\section{References}

Athanasoulis, S.G., \& Shiller, R.J. (2002). Defining residual risk-sharing opportunities: Pooling world income components. Research in Economics, 56(1), 61-84.

Hall, J.H. \& Brummer, L.M. (1999). The Relationship between the market value of a company and internal performance indicators. Management Dynamics, 8(3), 47 - 68.

Keller, C., \& Siegrist, M. (2006). Investing in stocks: The influence of financial risk attitude and values-related money and stock market attitudes. Journal of Economic Psychology, 27(2), 285-303

Lin, H.C., Chou, T.K., \& Cheng, J.C. (2011). Does market misvaluation drive post-acquisition underperformance in stock deals? International Review of Economics \& Finance, 20(4), 690-706.

Machuga S. M., Peeiffer P. J., \& Verma, K. (2002). Economic value added, future accounting earnings, and financial analysts' earnings per share forecasts. Review of Quantitative Finance and Accounting, 18, 59-73 .

Magni, C.A. (2009). Splitting up value: A critical review of residual income theories. European Journal of Operational Research, 198(1), 1-22.

Magni, C.A. (2010). Residual income and value creation: An investigation into the lost-capital paradigm. European Journal of Operational Research, 201(2), 505-519.

Pan, M.S. (2007).Permanent and transitory components of earnings, dividends, and stock prices. The Quarterly Review of Economics and Finance, 47(4), 535-549

Reddy Irala, L.R. (2005). EVA: The Right Measure of Managerial Performance. Indian Journal of Accounting and Finance, 119(2), 1-10.

Worthington, A., \& West, T. (2004), Australian evidence concerning the information content of economic value added, Australian Journal of Management, 29(2), 241. 